\title{
Research on Current Situation and Strategy of Online Marketing of Plateau Summer vegetables in Gansu
}

\author{
Jing $\mathrm{Xu}^{1, \mathrm{a}}$ and Huimin Huang ${ }^{1}$ \\ ${ }^{1}$ School of Economics, Northwest Minzu University, Lanzhou, Gansu, China
}

\begin{abstract}
This paper pointed out that there were a series of problems in the development of Gansu plateau summer-vegetables online marketing such as the lagging online marketing subject, the low application rate of rural internet and the low standardization and branding of products as well as the imperfect product distribution system and so on. In order to deal with these problems effectively, this paper suggested that Gansu province not only should cultivate the online marketing awareness of all relevant parties and improve the popularization rate of rural networks, but also should build a standardized system and a high-qualified plateau summer food brand. In addition, it is also of much importance to perfect the plateau summer vegetables distribution mode.
\end{abstract}

\begin{abstract}
Acknowledgement. This article is supported by the national information e-commerce key laboratory of Gansu province's higher education institutions. Also, it is the result of the opening phase of the laboratory of Northwest University for Nationalities (Project Approval No: SYSKF - 2018096).
\end{abstract}

\section{Related concepts and research status at domestic and western}

It is the plateau summer vegetables which are the vegetables planted and processed in high altitude areas by utilizing the climate characteristics of cool summer and sufficient light as well as large temperature difference between day and night in the northwest plateau region.[1]There are many varieties of plateau summer vegetables, mainly including the lettuce, chili, celery, cabbage, cauliflower, tomato, garlic moss, onion, yam, wax gourd, golden melon, sweet potato, etc. Online marketing is to realize the marketing goal with the power of online network, computer communication and digital interactive media. Its characteristics mainly include the low cost, high efficiency, wide dissemination, and good effect as well as timely information. ${ }^{[2]}$ Online marketing of agricultural products, which also is known as direct online marketing, refers to a new marketing method that uses information technology to fully import electronic commerce systems and relies on agricultural product production bases and logistics distribution systems so as to fully open up online marketing channels of agricultural products. ${ }^{[3]}$

Foreign scholars mainly analyze the relevant topics in terms of the advantages of online marketing and the characteristics of agricultural products online marketing methods in various regions of various countries. And the main methods of analysis is qualitative, while the quantitative analysis methods are rarely be utilized. ${ }^{[4][5][6]}$ [7] [8] [9]

Domestic scholars mainly analyze the relevant topics about online marketing from the perspective of network marketing mode, development status of various regions, and development status of certain products. And the main method of analysis is qualitative, while no quantitative analysis method is found. [10] [11] [12]

Plateau summer cuisine is one of the agricultural products projects that Gansu province has focused on in recent years. Due to its short development time, there is a great lack of in-depth and systematic theoretical research on it. This paper utilized electronic platforms and field survey data to conduct qualitative research on the current situation and strategies of e-commerce online marketing.

\section{The development status and existing problems of plateau summer vegetables online marketing in Gansu province}

\subsection{The subject of online marketing development lags behind}

\subsubsection{Inactive participation in the e-commerce activities}

At present, Gansu province has established 10 state- level and 44 provincial-level pollution-free vegetables

a.Corresponding author: 1037007123@qq.com 
standardization production demonstration base counties. The government mainly promotes "plateau summer vegetables", which are dominated by superior vegetables products such as cauliflower, broccoli, cabbage, and baby food, so that it can become the new highlight of agricultural products in Gansu province. However, there are many problems during the actual situation:

Lanzhou international plateau summer vegetables non-staple food purchasing center project is not only one of the eight major commodity trading markets approved by Gansu province, but also is the largest international agricultural and sideline products distribution center in northwest China. And it has been named "national public welfare market" by the Ministry of commerce and been listed as "3341" key project in Gansu province and major construction projects in Lanzhou city as well as been included in the "the belt and road initiative" project library and "PPP" project library in Gansu province. The project is located in Dingyuan town, Yuzhong county, Lanzhou city, Gansu province. It is also adjacent to national roads, expressways and railway lines and has remarkable traffic advantages. The positioning of this project is the wholesaling distribution center of plateau summer in Gansu province and it should also be the main subject of plateau summer e-commerce marketing activities. However, judging from the survey data on the network platform, the current level of e-commerce development of the project is very low, and few merchants and related products belonging to the project are found on mainstream e-commerce platforms such as Alibaba, JingDong and Taobao.

In addition, aiming at "playing green cards and building longzhong green industrial base", Huining county of Baiyin city in Gansu province vigorously develops pollution-free vegetables according to local conditions and turn 14 villages and towns such as Nakagawa, Dagou, and Hanji into key villages and towns for vegetables cultivation with planting 27,500 $\mathrm{Mu}$ of plateau summer vegetables. However, at present, farmers still adopt traditional marketing methods to conduct centralized purchasing at acquisition points so as to put into the market without using the e-commerce platforms.

\subsubsection{The concept of management subject is conservative}

Due to the influence of living environment, economy, transportation and other factors, most farmers are conservative in their concepts and generally have low and lagged awareness of the acceptance and application of the internet. Besides, most farmers are also weak in their awareness of using the internet to engage in commercial activities. Many growers are more willing to adopt traditional entity marketing methods than to accept online marketing methods.

\subsubsection{Lack of network marketing talents}

Gansu province belongs to the underdeveloped areas in the west, and rural education is relatively backward. At the same time, graduates of e-commerce major in colleges and universities are also reluctant to go deep into rural areas and engage in e-commerce of agricultural products that have not yet formed economic advantages.

\subsection{Rural network information infrastructure lags behind}

In recent years, due to the weak financial and material resources of the Gansu provincial government, the popularization rate of network infrastructure in rural areas is truly insufficient, at the same time, rural farmers have low incomes and high cost of internet access as well as low level of hardware and software allocation to carry out online marketing of agricultural products. In addition, it is also difficult to circulate and share information on supply and demand of agricultural products with the low rate of application of internet commerce. Based on such factors, rural farmers thus missed plenty of business opportunities. As a leading enterprise such as Lanzhou international plateau summer vegetables and non-staple food purchasing center, the infrastructure construction of computers and networks is also relatively backward. Most of the stronger enterprises deal with the business affairs with customers through internal information service departments without establishing a network platform for online marketing actually. Also, there are no agricultural information network which should been established among farmers, enterprises and agricultural product production bases. Besides, no attention has been paid to carrying out the characteristic agricultural product network online marketing.

\subsection{The low level of standardization and branding of agricultural products}

Fresh agricultural products with standard specifications, brands, and a certain degree of popularity will often achieve better results in online promotion and online sales. [13] The low level of standardization of agricultural products in Gansu province could be reflected on the factors as followings. For instance, firstly, the current agricultural standards seldom refer to international and national standards; Secondly, the standard system is not uniform, which easily leads to conflicts between national standards, local standards and industry standards. Furthermore, there is no standardization in the whole process of agricultural product production, and there are also few standards for seed and agricultural product production. In short, the main reason is that the scale of rural land management and production in Gansu province is relatively small and the spatial distribution is scattered, which is not conducive to standardized production.

The degree of branding of plateau summer vegetables in Gansu province is relatively low, which is mainly manifested in the following aspects: first of all, the number of brand are relatively less and there are lacking of well-known brands with influence; Secondly, the brand awareness is weak, while the brand innovation and brand marketing ability are poor; Thirdly, there are no existed excellent brand protection system. The government has not formulated relevant brand protection laws and 
regulations and thus cannot effectively monitor the use of brands. According to the survey of Taobao platform, a large number of Gansu province's agricultural products e-commerce companies have few understanding of the brand of plateau summer. These merchants are only familiar with the types and nature of the products, but do not understand the online marketing of characteristic agricultural products and also do not realize the advantages that plateau summer will bring. For example, during the investigation of the Taobao shops with good credit such as Tasty Northwest and Lvfeng Agricultural Garden as well as the Precious Baby of Gansu specialty shops, when being consulted some questions about plateau summer brand, the answers of them were always ambiguous with no clear brand awareness.

\subsection{The incomplete logistics and distribution system of agricultural products}

Plateau summer vegetables are seasonal, fresh and perishable. After being sold through the platform of the internet, the products eventually need to be delivered to consumers through the logistics and distribution system. The main market for plateau summer is focusing on the southeast coastal area of our country and Southeast Asian countries or regions. In general, the logistics and distribution problems that hinder agricultural products network marketing mainly reflected on the following factors. First of all, agricultural products fresh-keeping technology is not good. And rural transportation facilities are poor as well. Moreover, Gansu province is located in the northwest of our country, which basically relies on the transportation ways of road and railway. Therefore, logistics takes a long time with resulting in high unit transportation cost. At present, there is basically no own logistics company in the main business of Lanzhou international plateau summer vegetables and non-staple food purchasing center. So did the e-commerce on the network platform. After obtaining the orders, the main business affairs of logistics distribution are to be carried out through the third party logistics company.

\section{The development countermeasures of Gansu province plateau summer vegetables network marketing}

\subsection{Accelerate the construction project of rural networks and change the market concept of farmers}

The Gansu provincial government should regard the agricultural product network information of plateau summer vegetables as a quasi-public product and give certain financial support to the agricultural information network construction. Besides, the government should come forward to cooperate with network operators to jointly build network infrastructure and provide government subsidies when farmers purchase computers and related network equipment and continuously improve the internet access conditions in rural areas as well as encourage farmers to contact with e - commerce and assign professionals to train growers to conduct e-commerce activities so as to jointly build agricultural product network marketing platforms. In addition, based on the actual situation of plateau summer vegetables producing areas, the government can establish online marketing demonstration sites in areas with large planting scale of some advantageous products such as establish the lotus and celery demonstration sites in Dingyuan town, encourage the Lanzhou international plateau summer vegetables purchasing center and scattered farmers to query and publish product information through the approaches of internet.

\subsection{Pay attention to the training of network marketing personnel and agricultural information technology training}

On the one hand, government need to introduce professional personnel of marketing management as well as the technology of agricultural products online marketing so as to promote industrial development effectively. On the other hand, it is also necessary to focus on training agricultural production enterprises and farmers as well as other online marketing subjects. Generally, the training content should include basic knowledge of online marketing, basic knowledge of electronic commerce, basic computer operations, agricultural information collection, sorting, classification and distribution, online image processing of agricultural products as well as search engine operations and so on. In addition, it is important to train full-time agricultural information network staff in the contents of agricultural policies and regulations, basic professional knowledge of plateau summer vegetables, agricultural information network website design, web-page making, back-end operation and network maintenance and so on. Furthermore, it is of much significance to organize local government leaders to learn about the current development of Chinese e-commerce and the future development trend of e-commerce so as to enhance the online marketing awareness of leaders at all levels.

\subsection{Building a standardized platform and establishing a plateau summer vegetables brand}

\subsubsection{Improve the standardization level of plateau summer vegetables products}

In order to carry out the promotion of plateau summer vegetables network, the government should issue corresponding policies and increase funds to support the standardization construction of products so as to ensure the production quality of agricultural products. Relevant departments of Gansu provincial government should formulate relevant agricultural product standardization policies and regulations as soon as possible, which should cover every link from seed selection to sales of plateau summer vegetables, so that the entire production process of plateau summer vegetables can be strictly supervised. And it can possess both excellent quality and standardized 
packaging so as to enhance consumers' trust and increase product sales.

\subsubsection{Enhance the brand awareness of plateau summer vegetables}

The Gansu provincial government should actively develop the plateau summer vegetables brand and take the plateau summer vegetables brand as an opportunity to establish a good reputation for the quality of agricultural products in Gansu province. In addition, relevant management departments should not only enhance brand awareness, but also should actively guide and help producers to do a good job in brand building and promotion. Through increasing the popularity of plateau summer vegetables and the trust of the people who are in demand to the brand, the market share at domestic and abroad will be significantly consolidated and expanded. At the same time, it is also important to vigorously carry out quality certification and do a good job in product quality from the source of production as well as promote brand building through standardization so as to enhance the competitiveness of agricultural products markets through the practical and potential brand advantages.

\subsection{Improve the logistics distribution mode and implement the professional distribution of plateau summer vegetables}

Typically, it is the plateau summer vegetables which can be combined with two logistics distribution modes as following:

One is the self-supporting logistics mode, which is operated and managed by the agricultural product management enterprise itself. That is, after picking or processing the plateau summer vegetables, the enterprise or peasant household will complete the collection and distribution. Lanzhou international plateau summer vegetables and non-staple food purchasing center can rely on its policy advantages to raise funds from the government or other investors to establish its own logistics company so as to shorten the distribution time of plateau summer vegetables and reduce transaction costs. Besides, plateau summer vegetables business enterprises or farmers can simply sort and package the orders after receiving them online and then distribute them immediately so as to realize the objectives of distribution on the same day and the delivery within the time limit and improve the circulation speed as well as control the quality of logistics service. The second is the third-party model. The plateau summer vegetables business enterprises or farmers can also outsource the logistics and distribution business affairs to the third-party logistics companies such as S.F. Express, Y.T. Express, EMS, etc., and sign long-term and stable cooperation agreements with them. Obviously, the third-party mode is beneficial to plateau summer vegetables business enterprises or farmers to concentrate resources on production and marketing, thus further saving transaction costs. To sup up, the combination of the self-supporting mode and the third party mode can make the logistics distribution of the operator not completely depend on the third party logistics company. Even if the third party logistics enterprise abandons the orders during the period time of peak, it still will not have a greater impact on the reputation of the operator so that avoid the double losses of the operator and the consumer.

\section{Summary}

As the most active marketing mode at present, online marketing has opened up new sales channels for Gansu province to develop plateau summer vegetable industry. More importantly, relevant government departments should not only vigorously publicize and promote online marketing and give support to policies, funds and personnel, but also should establish a supporting standardized guarantee system as soon as possible. In addition, the concept of operating enterprises and farmers needs to be changed as well. And it is obvious that they should actively participate in the planting of plateau summer vegetables and online marketing activities. Moreover, relevant participants should also strengthen their brand awareness with actively building and promoting the local brand of plateau summer cuisine so that the plateau summer vegetables industry in Gansu province can get rapid development as soon as possible.

\section{References}

1. Changchun $\mathrm{Xu}, \mathrm{Ge}$ Zheng, Shanming Nie, Development status, existing problems and countermeasures of plateau summer food industry based on investigation in Yuzhong county, Gansu province [G]. Science and technology development center of Ministry of agriculture, 2, 53-56, (2016).

2. Hongxin Li. Introduction to electronic commerce [M]. Dalian: northeastern university of finance and economics press, 112, (2012).

3. Wuguo Gao, Lutao Li, Yaohui Xu. Electronic commerce and online marketing of agricultural products [M]. Beijing: Hina agricultural science and technology publishing house, (2015).

4. Levy Caracota, Andrew Whiston. E-commerce frontier [M]. Beijing: Tsinghua University publishing house, 2, (2004).

5. WARD H. Principles of Interne Marketing [M]. South Western College Publishing, 56-59, (2002).

6. Constance HmcLaren, Bruce J?6?7Mclaren. E-commerce-Business on the Internet. South-Western Educational Publishing, 5, 11-12, (2000).

7. Armstrong, Kotler. Marketing principles [M]. Beijing China people's publishing house, (2007).

8. Calva Ryan. Information rules [M]. Beijing: Renmin university of China press, (2000).

9. Adria, Ansley, Voski. Discovered profit zone [M]. Beijing: Citic Press, (2009).

10. Yufa An. Developing a new production and marketing docking model to stabilize the price of fresh agricultural products - "agriculture supermarket docking" and thinking about diversification [G]. China farmers' cooperative, (2011). 
11. Rong Zhang. Current situation and suggestions of online marketing of agricultural products [G]. Commodities and quality, 1, (2012).

12. Shue Yin. Research on online marketing model of plateau summer cuisine in Yuzhong County [G]. New marketing, (2015).
13. Xia Wang. Research on current situation and countermeasures of Hainan agricultural products online marketing [D]. Haikou: Hainan University, (2015). 